\title{
An interpretation of the statutory term "worker": a reply to Geare
}

\author{
Isaacus K. Adzoxornu*
}

\section{Introduction}

Under normal circumstances, I would have allowed Geare (1991) to indulge himself in the erroneous view that the interpretation of the term "worker" in the Labour Relations Act 1987 is confined to the common law "employee". It is necessary however, to come out to defend my original thesis (Adzoxornu, 1990) that the term need not be so narrowly construed. Geare seeks to demonstrate, without the relevant historical or policy considerations, and more importantly, without the relevant canons of statutory construction, that his counter thesis is "in fact clearly superior" to mine (p.193). It is clear from the Geare's comment that he considers modern New Zealand industrial legislation to have preserved the master and servant relationship. The purpose of this reply is to reassert my original thesis that the definition of "worker" in the Labour Relations Act is liberal enough to cover an independent contractor and to demonstrate that the counter thesis of Geare is too conservative to meet the requirements of modern industrial relations. I shall achieve this purpose by addressing Geare's counter thesis under his own subheadings.

\section{Parliamentary intent}

Geare's first argument is that in popular usage, "worker" and "employee" are regarded as "largely" synonymous (p.194). The fact that he chooses to use the word "largely" means that he recognizes that there is in even popular usage, a reasonable doubt as to whether the 2 terms are synonymous. This is not all. It is also necessary to point out that we are here, not dealing with the popular usage of the terms. We are instead dealing with the statutory definitions of the terms. The popular usage of the terms have ceased to apply because Parliament has considered it necessary to redefine the terms. There is, therefore, no point in giving the terms their popular meanings.

Geare then challenges my observation that Parliament possesses sufficient sophistication to differentiate the one from the other term (p.194). In so doing, he refers to the introduction in 1970 of the personal grievance procedure and claims that the amendment of the Industrial Conciliation and Arbitration Act 1954 intended "wrongful" to mean "unjustifiable" dismissal, but because Parliament was not sufficiently sophisticated, it enacted the former instead of the latter term. There are at least 2 serious flaws in the Geare's example. First, the term "wrongful" was not defined in the amending legislation (Industrial Conciliation and Arbitration Act s179(1)). It is difficult, if not impossible, to rely on the undefined concept of "wrongful" dismissal to make the point that Parliament did not know what it was doing. We are fortunate enough to have in the Labour Relations Act and other enactments the contrasting definitions of "worker" and

* Faculty of Law, Victoria University of Wellington. 
"employee" from which we can determine the real intent of Parliament. This opportunity did not exist under the 1970 amendment.

The second flaw in the Geare's example is its historical inaccuracy. In Parliament, the Minister who introduced the amending Bill was emphatic that it was intended to provide only a "procedure" for handling wrongful dismissal disputes. He considered the procedure a panacea to the numerous work stoppages due to alleged "wrongful" dismissals. When questioned further whether the procedure would mean any change in the concept of wrongful dismissal, the Minister was emphatic that it would not. The Bill, he said, was aimed at:

wrongful dismissal - that is, a dismissal that is not justified by law. This is clearly understood by the parties. If we added the words "or unfairly" it would open up the whole range of dismissals, whether they were lawful or not. It is certainly not the intention to do that (NZ Parliamentary Debates, Vol 369, 1970: p 4072).

I felt some initial hesitation to be the one to point out this historical inaccuracy in Geare's argument. However, I considered it necessary in order to show that on some occasions our elected representatives know what they are doing. We may not always agree with them, but that is not the issue here.

Geare's next argument is that I am incorrect in observing that Parliament intended to confine "employee" to a person who works under a contract of service. He relies on the definition of "employee" in the Equal Pay Act 1972 which I quoted in part (p.66). Even suppose I was incorrect in this conclusion, the observation only advances a strand of my thesis that statutory definitions sometimes change the meaning of common law concepts. I am, therefore, grateful to Geare for pointing out that the definition of "employee" in the Equal Pay Act 1972 envisages more than the common law contract of service.

The Employment Contracts Act 1991 defines "employee" with the same words as those chosen by the Labour Relations Act to define "worker". However, the same Act in repealing and substituting section 2(1) of the Parental Leave and Employment Protection Act 1987 defines "employee" as: "any person of any age employed by an employer to do any work for hire or reward, but does not include an independent contractor."

This provision vindicates my thesis in relation to the meaning of "worker" in the Labour Relations Act. It is important to understand that statutory definitions do not necessarily preserve traditional values. Statutory definitions, more often than not, are "less concerned with the expression of values than with the realization of practical goals conceived in utilitarian terms and pursued according to canons of scientific reasoning" (Abel, 1973, p.186).

\section{Industrial tribunals}

The purpose of my thesis is to challenge the interpretation which industrial tribunals have placed on the term "worker" so Geare's arguments about my stance under this heading do not, therefore, raise any issues that need replying to.

\section{Role of Unions}

I still maintain that it is not the province of the Labour Court to make or unmake a worker for the purposes of the Labour Relations Act. I still consider the province to belong to unions. My interpretation of "worker" is intended to achieve consistency in the Act. The Act cannot intend in one section to restrict its protections to the common law employee and proceed in the provisions which create access to the enjoyment of those protections, to recognize also categories outside the common law employee. As I discuss 
at p.73 of my article, sections 58(a) and 60 of the Act recognize "all persons working" and "every person who by virtue of that person's work or intended work", respectively, as having a right to join unions as the only means to the enjoyment of the protections of the Act.

Geare does not show anywhere in his comment that I have interpreted the union membership provisions of the Act incorrectly. He cannot do this because he is aware that no eligibility qualification, apart from the requirement that a person should be working or should intend to work, have been imposed under the Act on potential trade union members. Unless he can construe "work" or "working" to mean work or working under a contract of service, he will not have any case.

Geare is also aware of the unfettered discretion conferred on unions to formulate their own membership clauses. As a result he does not challenge my interpretation of this discretion. Instead of so doing, he reacts back to the definition of "worker" and observes that it is not defined as "any one covered by a union's membership clause" (p.195). Obvious again is the desperate effort to redeem the employee who, for all these years has sold his or her birthright to the statutory worker.

\section{Interpretation}

There are serious credibility gaps in Geare's exercise in statutory interpretation. According to Geare, "the fact [the definition of 'worker'] refers to a person being 'employed' is suggestive of a contract of service only, given that popular usage refers to 'engaging' a contractor ..." (p.195-196). The Collins English Dictionary (1985) defines "employ" as "to engage or make use of the services of (a person) in return for money; hire; to provide work or occupation for; keep busy; occupy". The same source defines "engage" as "to secure the services of; employ". The Concise Oxford Dictionary (1976) also defines "employee" as: "use services of (person); keep (person) in one's service; busy, keep occupied ...." The latter source also defines "engage" as: "bind by contract ...; hire (servant, employee)". There does not appear to be any difference in the ordinary meanings of the 2 terms. It is, therefore, suggested that Geare is not correct in his observation that one cannot "employ" an independent contractor. An independent contractor may be "employed" or "engaged" as much as the common law employee under section 2 of the Labour Relations Act. Clear words will be necessary to exclude an independent contractor from being "employed" for hire or reward.

Geare also seeks to preserve his narrow definition of "worker" by an appeal to the exclusio unius est exclusio alterius rule of statutory construction (p.196). The authorities will, however, indicate that the attempts here are, if anything, an abuse of this residual rule of construction. The Labour Relations Act defines worker to "include" a homeworker. The ordinary understanding, whenever "include" is used is that the categories which follow are only examples of what is intended or envisaged (Maxwell,1969, p.270-271).

One might wish to contrast the Chancery Tavern Ltd case ${ }^{1}$ with Thorby. ${ }^{2}$ In the former, Palmer J made an order for the "limited reinstatement" of a worker-grievant apparently on the basis that section 227(a) of the Labour Relations Act confers jurisdiction on the Court by virtue of the word "including", to create other forms of reinstatement beside those expressly mentioned in the subsection. In the latter case, however, the Arbitration Court considered that there was no scope in section 117(7) of the Industrial Relations Act 1973 for a grievance committee to order a worker's reinstatement to a position which involved less hours of work. This was so because the latter subsection expressly mentioned only 2 forms of reinstatement.

$1 \quad$ [1988] NZILR 1465.

2 [1981] ACJ 199. 
It will make no difference whether the word "include", "including" or "includes" is used in the interpretation provision of an Act. As Langan (1969, p.270) observes:

[T] he word "include" is used "in order to enlarge the meaning of words or phrases occurring in the body of the statute; and when it is so used these words or phrases must be construed as comprehending, not only such things as they signify according to their natural import, but also those things which the interpretation clause declares that they should include". In other words, the word in respect of which "includes" is used bears both its extended statutory meaning and "its ordinary, popular, and natural sense whenever that would be properly applicable.

Geare might wish to reconsider his argument in this context.

\section{Conclusion}

It will now be obvious that Geare has no solid contribution to make to the debate whether "worker" in the Labour Relations Act means only a person who works under a contract of service or whether it means also a person who works under a contract for services. I still maintain that Parliament has made its intention explicit enough that "worker" is not necessarily confined to the common law employee. The argument that I am incorrect to so assert because Parliament has not changed the definition of "worker" for nearly 100 years, may be countered in 2 ways. The first is that, so far, the claims before our industrial tribunals have not been whether the definition of worker can be extended to also an independent contractor. All the claims have been whether a person works or worked under a contract of service. One must admit that claimants themselves have not directed their attention to the liberal definition of the term. The second is that academic writers such as Geare (1988, p.65-66) have failed to point out that the definition is liberal enough to cover the independent contractor. One cannot explain this failure in any real terms; however, it has succeeded in misleading everybody including judges of industrial tribunals. Put together, these 2 reasons would explain why Parliament has never had the opportunity to review the application of the definition to actual industrial relations practice.

It is, however, necessary to point out that this parliamentary inertia cannot serve as an Ark of Israel for Geare's counter thesis. The fact that a particular law has not been changed for 2,000 years is no concrete proof that the law has been applied correctly for all those years.

\section{References}

Abel, R.L. (1973) Law books and books about law. Stanford law review 26:175-.

Adzoxornu, I.K. (1990) The 'worker' the Labour Court and the common law in New Zealand: A holy trinity?" New Zealand journal of industrial relations 15(1):61-78.

Geare, A.J. (1988) The system of Industrial relations in New Zealand. Wellington, Butterworths (2nd edition).

Geare, A.J. (1991) An interpretation of the statutory term "worker": a comment. New Zealand journal of industrial relations 16(2):143-146.

Langan, P. (1969) Maxwell on interpretation of statues. London, Sweet \& Maxwell (12th edition). 